\title{
Comparison between in vitro embryo production in Bos indicus and Bos taurus cows
}

\author{
Comparação entre a produção in vitro de embriões em fêmeas Bos indicus e Bos taurus \\ Comparación entre la producción de embriones in vitro en vacas Bos indicus y Bos taurus
}

Received: 06/01/2021 | Reviewed: 06/08/2021 | Accept: 06/11/2021 | Published: 06/26/2021

\author{
Graziela Alves de Lima Moschini \\ ORCID: https://orcid.org/0000-0002-3299-1211 \\ Fundação Araucária, Brazil \\ Universidade Estadual do Norte do Paraná, Brazil \\ E-mail: grazielaalmoschini@gmail.com \\ Douglas Gaitkoski \\ ORCID: https://orcid.org/0000-0001-7583-1210 \\ Pecpaln ABS Importação e Exportação LTDA, Brazil \\ E-mail: douglas.gaitkoski@genusplc.com \\ Ana Beatriz Marques de Almeida \\ ORCID: https://orcid.org/0000-0003-2659-4786 \\ Universidade Estadual de Londrina, Brazil \\ E-mail: biamarquesvet30@gmail.com \\ Myrian Megumy Tsunokawa Hidalgo \\ ORCID: https://orcid.org/0000-0003-4650-029X \\ Universidade Estadual de Londrina, Brazil \\ E-mail: myrianhidalgo@ hotmail.com \\ Maria Isabel Mello Martins \\ ORCID: https://orcid.org/0000-0001-8416-2450 \\ Universidade Estadual de Londrina, Brazil \\ E-mail: imartins@uel.br \\ Wanessa Blaschi \\ ORCID:https://orcid.org/0000-0002-6161-6576 \\ Laboratório de Biotecnologia da Reprodução Animal, Brazil \\ Universidade Estadual do Norte do Paraná, Brazil \\ E-mail: wblaschi@uenp.edu.br \\ Thales Ricardo Rigo Barreiros \\ ORCID: https://orcid.org/0000-0001-8735-5901 \\ Laboratório de Biotecnologia da Reprodução Animal, Brazil \\ Universidade Estadual do Norte do Paraná, Brazil \\ E-mail: thalesrigo@uenp.edu.br
}

\begin{abstract}
The aim of this study was to evaluate the in vitro embryo production in Bos taurus and Bos indicus donors, evaluating from oocyte recovery to final embryo production. Data were collected during the months of January and February and August to October 2017. Bos taurus cows: Holstein and Senepol and Bos indicus cows: Nelore and Dairy Gir, were used as oocyte donors. In total, 3622 sessions of OPU were performed, divided between: Holstein donors: 925; Senepol donors: 1055; Nelore donors: 1202 and Dairy Gir donors: 440. In total, 103.399 oocytes were recovered, being viable oocytes: 90.807 ; cleaved: 65.252 and produced embryos: 24216 . There was no statistical difference between the genetic groups for the total oocytes recovered (Bos taurus: 25.5 vs. Bos indicus: 30.1; P> 0.05). However, a statistical difference was observed between the cleaved (Bos taurus: 16 vs. Bos indicus: 20.4; $\mathrm{P}<0.05$ ) and produced embryos (Bos taurus: 4.4 vs. Bos indicus: 8.3 ; $\mathrm{P}<0,05$ ). Thus, the conclusion is that Zebu donors perform better in IVEP and the donor breed influences the IVEP results.
\end{abstract}

Keywords: Donor; Bos taurus; Bos indicus; Oocyte; Embryos.

\section{Resumo}

O objetivo deste estudo foi avaliar a produção in vitro de embriões em doadoras Bos taurus (Holandês e Senepol) e Bos indicus (Nelore e Gir), avaliando desde a recuperação oocitária até a produção final de embriões. Os dados foram coletados durante dois períodos, os meses de janeiro e fevereiro e de agosto a outubro de 2017. Foram utilizadas como doadoras de oócitos, fêmeas Bos taurus: das raças Holandês e Senepol e fêmeas Bos indicus: das raças Nelore e Gir. No total foram realizadas 3622 sessões de OPU, divididas entre: doadoras da raça Holandês; 925, Senepol; 1055, Nelore; 1202 e Gir; 440. Foram recuperados 103.399 oócitos totais, sendo, oócitos viáveis: 90,807; clivados: 65,252 e embriões produzidos: 24216. Não houve diferença estatística entre os grupos genéticos para o número total de oócitos recuperados (Bos taurus: 25,5 vs Bos indicus: 30,1; P>0,05). No entanto, foi observado diferença estatística entre os clivados (Bos taurus: 16 vs Bos indicus: 20,4; $\mathrm{P}<0,05$ ) e embriões produzidos (Bos taurus: 4,4 vs Bos indicus: 8,3; $\mathrm{P}<$ 
0,05). Nas condições desse estudo pode se concluir que, doadoras zebuínas apresentam melhor desempenho na PIVE, e que a raça das doadoras pode interferir no resultado da PIVE.

Palavras-chave: Doadora; Taurinos; Zebuínos; Oócito; Embriões.

\section{Resumen}

El objetivo de este estudio fue evaluar la producción in vitro de embriones en donantes Bos taurus (holandés y Senepol) y Bos indicus (Nelore y Gir), evaluando desde la recuperación de ovocitos hasta la producción embrionaria final. Los datos se recolectaron durante dos períodos: enero y febrero y de agosto a octubre de 2017. Se utilizaron vacas Bos taurus como donantes de ovocitos: Holandesas y Senepol y vacas Bos indicus: Nelore y las razas Gir. En total, se llevaron a cabo 3622 sesiones OPU, divididas entre: donantes holandeses; 925, Senepol; 1055, Nelore; 1202 y Gir; 440. Se recuperaron 103.399 ovocitos totales, con ovocitos viables: 90,807; escindidos: 65,252 y embriones producidos: 24216. No hubo diferencia estadística entre los grupos genéticos para el número total de ovocitos recuperados de vacas (Bos taurus: 25,5 vs Bos indicus: 30,1; P> 0.05). Sin embargo, se observó una diferencia estadística entre los embriones escindidos (Bos taurus: 16 vs Bos indicus: 20,4; P <0,05) y producidos (Bos taurus: 4,4 vs Bos indicus: 8,3; P <0, 05). En las condiciones de este estudio, se puede concluir que los donantes de cebú presentan mejor desempeño en PIVE, y que la raza de donantes puede interferir en el resultado de PIVE.

Palabras clave: Donante; Taurinas; Ganado cebú; Ovocito; Embriones.

\section{Introduction}

The development of reproductive biotechniques is essential for increasing reproductive efficiency. In this context, in vitro embryo production (IVEP) is a useful and effective tool to increase the genetic gain, productivity, and reproductive performance of dairy and beef cattle (Baruselli et al., 2019). The number of embryos produced in vitro has been growing exponentially and currently, according to the International Embryo Transfer Society (IETS), this number has reached more than 1,000,000 embryos produced in vitro worldwide (IETS, 2019).

The IVEP main objective is to maximize the reproductive potential of bovine herds. The technique allows to obtain viable embryos from genetically superior animals: as healthy females or with reproductive alterations and cows in prepubertal age, pregnant (up to third month), and in the postpartum period (Mello et al., 2016). Thus, obtaining more progeny per donor (50 calves/cow/year) during the reproductive life, reducing the interval between generations (Loiola et al., 2014; Wrenzycki, 2016).

Technologies such as Ovum-pick-up (OPU) contribute to accelerating the genetic gain through both female and male lineage, considering that for the fertilization of the oocytes, semen from different bulls can be used for individual donors, optimizing the use of high zootechnical value breeders (Van Wagtendonk-De Leeuw, 2006) and enables the use of sexed semen (Brackett \& Zuelke, 1993; Bueno \& Beltran, 2008; Santl et al., 1998).

However, nutritional and technical factors, as well as individual characteristics of donors, affect the fertility and efficiency of IVEP. It is known that Bos taurus and Bos indicus genetic groups have their particularities in relation to reproductive characteristics and this variability between donors can influence oocyte recovery, oocyte quality, blastocyst production up to pregnancy rate (Monteiro et al., 2017; Pontes et al., 2010, Negreiros et al., 2020). Even so, the high repeatability of recovery in oocyte donors allows the identification of higher potential for oocyte production (Baruselli et al., 2015; Ireland et al., 2007; Ireland et al., 2008; Monteiro et al., 2017).

Therefore, studies exploring the productive capacity of embryos of Bos taurus, Bos indicus genetic groups, and the crossing between them, are fundamental for the selection of donors and the development of embryo technologies. The aim of this study was to compare the in vitro embryo production in Bos taurus donors (Holstein and Senepol) and Bos indicus donors (Nelore and Gir), evaluating from oocyte recovery to final embryo production. 


\section{Methodology}

\subsection{Ethical aspects}

This study was carried out in accordance with the Animal Experimentation Ethics Committee of the State University of Northern Paraná under number 03/2017, based on Federal Law 11.794, of October 8, 2008.

\subsection{Animals and oocyte recovery}

The study evaluated data collected from August to October 2017, of Pecpaln ABS Importação e Exportação LTDA., located in Uberaba, MG, Brazil. All procedures were performed by the same technicians. As oocytes donors it was used Bos taurus (Holstein and Senepol) and Bos indicus (Nelore and Gir) healthy and cyclic cows. There were no hormonal protocols in cows before the OPU sessions, all procedures were performed at random stages of the estrous cycle, with an interval of at least 15 days for each donor. In total, 3622 OPU sessions were held, divided between: Holstein donors; 925, Senepol; 1055, Nelore; 1202 and Gir; 440.

Follicular aspiration was performed according to the technique described by Seneda, Esper, Garcia, Oliveira, \& Vantini (2001), in which, each visible follicle was aspirated using a real-time B mode ultrasonography scanner (Scanner 200 Vet, Pie Medical, Maastricht, Netherlands), with a 7.5 MHz convex array transducer was fitted in an intravaginal device (Pie Medical) with a stainless steel guide. The follicular puncture was performed using a $191 / 2$ " disposable hypodermic needle (Becton Dickinson, Curitiba, PR, Brazil), connected to a $50 \mathrm{~mL}$ conical tube (Corning, Acton, MA, USA) via a silicone tube (0.8 m long; $2 \mathrm{~mm}$ id). Aspiration was performed using a vacuum pump (Cook Veterinary Products, Queensland, Australia) with negative pressure of $10-12 \mathrm{~mL}$ of water/min.

\subsection{In vitro maturation (IVM)}

Immediately after OPU and filtering, the cumulus-oocyte complexes (COC's) were classified as good: more than three layers of cumulus cells; regular: at least one layer of cumulus cells; naked and atretic: dark cumulus cells and irregular cytoplasm (Seneda et al., 2001), only atretic oocytes being discarded. After selection, the COC's were deposited in cryovials containing MIV $®$ medium (ABS, Uberaba, Brazil) and mineral oil and transported to the laboratory in a portable incubator (WTA $\odot$, Cravinhos, Brazil) at $39^{\circ} \mathrm{C}$. In the laboratory, oocytes were washed in LAV® medium (ABS, Uberaba, Brazil) and incubated (Thermo Fisher Scientific $\odot$, USA) in drops of $100 \mu \mathrm{L}$ (maximum 35 oocytes per drop) of MIV® medium (ABS, Uberaba, Brazil), under mineral oil, at $39^{\circ} \mathrm{C}$ with gas composition and humidity controlled $(5 \% \mathrm{CO} 2,5 \% \mathrm{O} 2$ and $90 \% \mathrm{~N} 2)$, for 22 to 24 hours.

\subsection{In vitro Fertilization (IVF)}

After maturation, oocytes were washed twice in drops of TL® medium (ABS, Uberaba, Brazil), twice in drops of FIV® medium (ABS, Uberaba, Brazil) and placed in 35x $10 \mathrm{~mm}$ Petri dishes (Corning®, USA), containing drops of FIV® medium (ABS, Uberaba, Brazil), under mineral oil.

For IVF, only frozen semen from the bull of known fertility were used. The semen was thawed in a water bath at $35^{\circ} \mathrm{C} / 20$ s, submitted to the selection of sperm fraction, using the Percoll@ gradient (ABS, Uberaba, Brazil) $90 \%(500 \mu \mathrm{L}$ ) and $45 \%(500 \mu \mathrm{L})$ in Eppendorf $(1,5 \mathrm{~mL})$. Then, semen was centrifuged $(9000 \mathrm{rpm} / 5 \mathrm{~min})$, the supernatant was removed and the pellet resuspended with FIV® medium (ABS, Uberaba, Brazil). New centrifugation was performed (2000 rpm / $3 \mathrm{~min}$ ), the supernatant was removed, and heparin $(11 \mu \mathrm{L})$ and PHE $(44 \mu \mathrm{L})$ were added to induce the sperm capacitation and to stimulate sperm motility, respectively. Concentration was adjusted to $25 \times 10^{6}$ motile sptz / $\mathrm{mL}$ and each fertilization drop $(100 \mu \mathrm{L})$ received $6 \mathrm{uL}$ of semen (final concentration $2 \times 10^{6} \mathrm{sptz} / \mathrm{ml}$ per drop), with sperm motility $\geq 70 \%$. 
For co-cultivation, Petri dishes were incubated in an incubator (Thermo Fisher Scientific @), USA) for fertilization, at $39^{\circ} \mathrm{C}$ with gas composition and humidity controlled $(5 \% \mathrm{CO} 2,5 \% \mathrm{O} 2$ and $90 \% \mathrm{~N} 2)$ for $20-22$ hours.

\subsection{In vitro cultivation (IVC)}

After IVF, the possible zygotes were washed in drops of TL® medium (ABS, Uberaba, Brazil) concomitant to mechanical stripping by successive pipetting. Then, they were washed and distributed in drops of C4® medium (ABS, Uberaba, Brazil) in $35 \times 10 \mathrm{~mm}$ Petri dishes (Corning®, USA), under mineral oil. This step was performed under the same temperature, gas composition, and controlled humidity, as the IVF procedure. Ninety and six hours after IVF (D4), 50\% of C4® medium (ABS, Uberaba, Brazil) was replaced, containing the possible zygotes, with a new C5® medium (ABS, Uberaba, Brazil) and cleavage rates were recorded. Then, they were incubated in an incubator (Thermo Fisher Scientific (C, USA) at $39^{\circ} \mathrm{C}$, with gas composition and humidity controlled (5\% CO2, 5\% O2 and 90\% N2) until D6. For evaluation of embryonic production rate, dead structures, degenerate or in process of degeneration were disregarded.

\subsection{Statistical analysis}

All data obtained were analyzed by the SigmaStat program (1999). The data did not present a normal distribution and were compared by non-parametric tests. The results by the genetic group were subjected to Mann-Whitney test and results by breed were subjected to variance analysis (Kruskal-Wallis) and Dunn's test ( $\mathrm{P}<0.05)$.

\section{Results and Discussion}

A total of 103,399 oocytes were recovered from 116 females in 3622 OPU sessions, only 85.517 were considered viable oocytes. For IVEP rate, a total of 24,216 embryos were obtained, being recorded 8.1 embryos produced / cow (Table 1).

There was no difference $(\mathrm{P}>0.05)$ between number of total oocytes and viable oocytes recovered in the OPU between the genetic groups. However, there was a difference $(\mathrm{P}<0.05)$ between breeds (Table 2$)$.

Table 1- Results of OPU and IVEP in Senepol, Holstein, Nelore and Gir cows, between August to October 2017.

\begin{tabular}{cc}
\hline Variables & $\mathbf{N}$ \\
\hline OPU & 3,622 \\
Total oocytes & 103,399 \\
Total oocytes/cow & 31.7 \\
Viable oocytes & 85,517 \\
Viable oocytes/cow & 28.3 \\
Cliaved & 65,252 \\
Cliaved/cow & 19.8 \\
Total embryos & 24,216 \\
Embryos/cow & 8.1 \\
\hline
\end{tabular}

Source: Moschini et al., (2021). 
Table 2 - Mean values (minimum - maximum) of total and viable oocytes recovered per cow, in OPU sessions in Bos taurus and Bos indicus genetic groups, between August to October 2017.

\begin{tabular}{lcccc}
\hline $\begin{array}{l}\text { Genetic } \\
\text { group }\end{array}$ & Breed & $\mathrm{n}$ & $\begin{array}{c}\text { Total oocytes } \\
(\text { minimum e maximum })\end{array}$ & $\begin{array}{c}\text { Viable oocytes } \\
(\text { minimum e maximum })\end{array}$ \\
\hline Bos taurus & & 1980 & $25.5(5.0-100)$ & $27.1(5.0-92)$ \\
& Holstein & 925 & $14.7(7.0-49)^{\mathrm{a}}$ & $13.2(8.0-47)^{\mathrm{a}}$ \\
& Senepol & 1055 & $35.4(7.0-154)^{\mathrm{b}}$ & $31.5(7.0-135)^{\mathrm{b}}$ \\
\hline Bos indicus & & 1642 & $30,1(7,0-154)$ & $22.4(4.0-132)$ \\
& & & $34.4(11.0-100)^{\mathrm{b}}$ & $30.0(11.0-92)^{\mathrm{b}}$ \\
& Nelore & 1202 & $24.7(5.0-45)^{\mathrm{c}}$ & $16.3(4.0-27)^{\mathrm{a}}$ \\
\hline
\end{tabular}

$\mathrm{P}<0,05$

* Different letters in the same column differ statistically.

Source: Moschini et al., (2021).

Regarding the mean values of cleaved embryos, produced embryos and embryo conversion rate, it was possible to observe a difference ( $\mathrm{P}<0.05)$ between genetic groups (Bos taurus and Bos indicus) and between breeds (Holstein; Senepol; Nelore and Gir). There was no difference between Senepol, Nelore, and Gir donors when evaluating the mean values of each breed separately. However, result obtained in Holstein donors was significantly lower compared to other donors. Data indicate that in all breed the mean values of cleaved oocytes and embryos produced were considerably lower than number of recovered oocytes (Table 3).

Mean values (minimum - maximum) of cleaved embryos, embryos per total of oocytes (\%) and embryos per cow, in OPU sessions in Bos taurus and Bos indicus genetic groups, between August to October 2017.

\begin{tabular}{|c|c|c|c|c|c|}
\hline \multirow{2}{*}{$\begin{array}{l}\text { Genetic } \\
\text { group }\end{array}$} & \multirow[t]{2}{*}{ Breed } & \multirow[t]{2}{*}{$\overline{\mathbf{N}}$} & Cleaved & Embryos \% & \multirow{2}{*}{$\begin{array}{c}\text { Embryos/cow } \\
\text { (minimum and maximum) }\end{array}$} \\
\hline & & & $\begin{array}{l}\text { (minimum and } \\
\text { maximum) }\end{array}$ & (embryos/oocytes) & \\
\hline \multirow[t]{6}{*}{ Bos taurus } & & 59 & $16.0^{\mathrm{A}}$ & $19.6^{\mathrm{A}}$ & $4.4^{\mathrm{A}}$ \\
\hline & & & $(4.0-106)$ & $(9811 / 50043)$ & $(0.6-68.0)$ \\
\hline & Holstein & 21 & $9.0^{\mathrm{a}}$ & $11.8^{\mathrm{a}}$ & $2.0^{\mathrm{a}}$ \\
\hline & & & $(4.0-106)$ & $(1697 / 14305)$ & $(0.6-4.4)$ \\
\hline & Senepol & 38 & $20,0^{\mathrm{bc}}$ & $22,7^{\mathrm{b}}$ & $8,0^{\mathrm{bc}}$ \\
\hline & & & $(4.3-30.3)$ & $(8114 / 35738)$ & $(1.0-68.0)$ \\
\hline \multirow[t]{2}{*}{ Bos indicus } & & 57 & $20.4^{\mathrm{B}}$ & $22.0^{\mathrm{B}}$ & $8.3^{\mathrm{B}}$ \\
\hline & & & $(4.0-68)$ & $(14355 / 53365)$ & $(2.0-25.5)$ \\
\hline
\end{tabular}




\begin{tabular}{|c|c|c|c|c|}
\hline Nelore & 33 & $\begin{array}{c}23.8^{\mathrm{b}} \\
(4-68,0)\end{array}$ & $\begin{array}{c}28.1^{\mathrm{c}} \\
(11785 / 41820)\end{array}$ & $\begin{array}{c}9.6^{\mathrm{b}} \\
(3.0-25.5)\end{array}$ \\
\hline Gir & 24 & $\begin{array}{c}23.8^{c} \\
(4-27.5)\end{array}$ & $\begin{array}{c}22.7^{b} \\
(2570 / 11536)\end{array}$ & $\begin{array}{c}6.0^{\mathrm{c}} \\
(2,0-14,7)\end{array}$ \\
\hline
\end{tabular}

$\mathrm{P}<0,05$

* Values followed by capital letters indicate a difference between genetic groups;

* Values followed by lowercase letters indicate differences between races.

Source: Moschini et al., (2021).

\section{Discussion}

In a retrospective analysis of data from a commercial IVEP program, Bos indicus and Bos taurus genetic groups, from oocyte recovery to embryonic production, results indicated that, although there was no variation between the genetic groups to the number of total and viable oocytes, there was a variation for recovery of oocytes by OPU between breeds (beef: Nelore $=$ 34.3 and Senepol $=35.4$; dairy: Gir $=24.7$ and Holstein $=14.7$ ), conforming with previous studies that reported variability of individual donors in reproductive characteristics between Bos indicus and Bos taurus cows for oocyte recovery, oocyte quality, blastocyst production up to pregnancy rate (Monteiro et al., 2017; Gimenes et al., 2015; Pontes et al., 2010; Sales et al., 2015). Thus, it is suggested that the breed should be considered when an IVEP program is established.

In our study, considering only beef breeds: Nelore (Bos indicus) and Senepol (Bos taurus), there was no variation in oocyte recovery between genetic groups $(\mathrm{P}>0.05)$. Similar results a study conducted by Pontes et al. (2010) who reported a mean recovery of 30 total oocytes in Nelore cows. On the other hand, in dairy breeds: Gir (Bos indicus) and Holstein (Bos taurus), a difference was observed in oocyte recovery ( $\mathrm{P}<0.05)$, corroborating with other studies also carried out in Gir and Holstein cows, in which Gir donors showed better results in oocyte recovery (Pontes et al., 2010; Silva et al., 2015). These results were already expected, as Bos indicus cows generally exhibit three follicular waves (Baruselli, Gimenes, \& Sales, 2007; Silva-Santos et al., 2011), consequently having more ovarian follicles, resulting in a greater number of oocytes recovered by OPU (Lacerda et al., 2020; Viana et al., 2004; Xu et al., 2006).

In Bos taurus cows (Senepol: 35.4 vs. Holstein: 14.7; P <0.05), higher values of oocyte recovery were observed for Senepol donors. In this case, the results can be explained because Holstein cows are more susceptible to heat stress than Senepol cows, which are considered more thermotolerant. Confirming studies that reported that heat stress had a negative effect on oocyte competence of Holstein donors (Ferreira et al., 2011; Paula-Lopes et al., 2003; Watanabe et al., 2017). Despite differences observed a total number of oocytes recovered by OPU between breeds, it is noted that in all breeds the number of oocytes recovered by the individual donor was consistent over a period, that is, there was repeatability in oocytes production, corroborating with previous studies (Baruselli et al., 2015; Ireland et al., 2007; Ireland et al., 2008; Monteiro et al., 2017), is a relevant data for efficiency of IVEP worldwide (Monteiro et al., 2017).

In relation to the mean values of cleaved oocytes, lower numbers were observed for Holstein cows (Nelore: 23.8; Gir: 23.8; Senepol: 20.0 and Holstein: 9.0), which differed statistically from other donors $(\mathrm{P}<0.05)$, these results corroborate with Oliveira et al. (2013) who reported that Holstein cows have a lower cleavage oocytes rate because their oocytes have inferior quality. Studies suggest that cleavage and blastocyst rates in Bos taurus cows are similar to those obtained in Bos indicus cows, but with divergent results, demonstrating that this factor is probably more associated with oocyte quality than with breed factor (Pontes et al., 2010; Tamassia et al., 2003). 
The management and feeding of the animals are factors that may have influenced the results of the IVP and the variations observed in this study since the donors came from different properties and were submitted to different management conditions and climate. In addition, the susceptibility to heat stress in Holstein cows in warmer periods can also result in a lower blastocyst rate (Watanabe et al., 2017). Thus, the influence of the donors and of the male, in the oocytes production and in vitro embryos needs to be better elucidated.

Although the cleavage and blastocyst rates of individual bulls were not evaluated, different bulls of each breed were used and not just one bull, which may have influenced the results, as it is known that there is a variation between bulls at in vitro fertility rates (Alomar et al., 2008; Machado et al., 2009). This variability may be related to differences in sperm quality (Alomar et al., 2006; Gillan et al., 2008), microRNA expression (Govindaraju et al., 2012), sperm plasma membrane protein (Gaviraghi et al., 2010; Roncoletta et al., 2006) and sperm gene expression (Khatib et al., 2009). However, data indicate that after fertilization with sperm having intact DNA, part of development is controlled by the oocyte, including activation of the embryonic genome (Heikinheimo \& Gibbons, 1998), indicating that the effect of donor breed on embryo production is more relevant than bull breed (Lacerda et al., 2020).

Another evaluation carried out was the embryos number produced per cow $/$ breed (beef: Nelore $=9.6$ and Senepol $=$ 8.0; dairy: Gir $=6.0$ and Holstein $=2.0$ ). The results for dairy cows were similar to those reported by Pontes et al. $(2010)$. A possible factor for the low values referring to embryos produced by Holstein donors is that, because these cows have fewer follicles, probably they have a higher concentration of FSH and estradiol, which can be detrimental in oocyte maturation and consecutively in embryonic development (Ireland et al., 2009). Possibly Anti-Mullerian Hormone (AMH) concentration has a positive correlation with the number of total oocytes and viable oocytes recovered in the OPU, of oocytes suitable for cultivation, and also in blastocysts production, suggesting that $\mathrm{AMH}$ concentration can be used as an endocrine marker and predict in vitro production (Guerreiro et al., 2014). In addition, in a study carried out in Gir and Holstein donors, a higher number of PAPPA-mRNA was identified in oocytes and cumulus cells that is associated with pregnancy, and a lower expression of IGFBP4 in cumulus cells from Gir donors, suggesting an increase in the bioavailability of IGF-free, contributing to the oocyte competence of these donors (Lopes et al., 2017).

Production of embryos of Nelore cows achieved in our study was similar to that described in the literature, which indicates that Nelore cows produce more embryos in vitro compared to other breeds (Monteiro et al., 2017; Sales et al., 2015; Santos et al., 2008). Since Bos indicus cows have more oocytes of better quality compared to Bos taurus cows, and thus, they express a greater number of genes related to cellular metabolisms, such as the glucose transporter (GLUT) 1 and the IGF-I receptor (IGF1R). These factors contribute to higher blastocyst rates in zebu donors, concluding that Bos indicus donors may have their oocytes more capable of undergoing in vitro maturation compared to Bos taurus donors (Sales et al., 2015).

Regarding Senepol donors, the literature is devoid of reports referring to IVEP, however, Heinzen et al. (2014) described an embryo rate of $30.65 \%$ in relation to the number of oocytes recovered from Senepol donors, higher than the average value $(22.7 \%)$ found in the present study. However, we can consider that for this study the results were satisfactory as well as in Bos indicus donors and that despite being from Bos taurus genetic group, the influence of individual factor and variation between the months of the year is suggested. These results give support to Watanabe et al. (2017) who reported that Senepol donors may have variation in blastocyst rates according to season of year. However, despite all the factors that may influence the IVEP performance, Bos indicus donors are still better at in vitro embryo production than Bos taurus donors (Sales et al., 2015; Santos et al., 2008).

In general, a difference was observed between genetic groups to in vitro embryos production, demonstrating that Zebu donors present a better performance in IVEP. However, both in beef and dairy breeds, the number of embryos produced was higher in donors with a higher number of oocytes recovered by OPU, regardless of genetic group. This has been shown 
previously, in which possibly the variation in oocytes production interferes in the in vitro embryos production (Monteiro et al., 2017; Pontes et al., 2010).

Thus, it is relevant to identify donors with the greatest potential for oocyte recovery and can consider this as a determining factor for the IVEP success.

\section{Conclusion}

Thus, it is relevant to identify donors with the greatest potential for oocyte recovery and can consider this as a determining factor for the IVEP success.

\section{Acknowledgments}

The authors thank Pecpaln ABS Importação e Exportação LTDA.

\section{References}

Alomar, M., Mahieu, J., Verhaeghe, B., Defoin, L., \& Donnay, I. (2006). Assessment of sperm quality parameters of six bulls showing different abilities to promote embryo development in vitro. Reproduction, Fertility and Development, 18(3), 395-402. https://doi.org/10.1071/RD05132

Alomar, M., Tasiaux, H., Remacle, S., George, F., Paul, D., \& Donnay, I. (2008). Kinetics of fertilization and development, and sex ratio of bovine embryos produced using the semen of different bulls. Animal Reproduction Science, 107(1-2), 48-61. https://doi.org/10.1016/j.anireprosci.2007.06.009

Baruselli, P. S., Batista, E. O. S., Vieira, L. M., \& Souza, A. H. (2015). Relationship between follicle population, AMH concentration and fertility in cattle. Anim. Reprod, 12(3), 487-497.

Baruselli, P. S., Gimenes, L. U., \& Sales, J. N. S. (2007). Fisiologia reprodutiva de fêmeas taurinas e zebuínas. Revista Brasileira de Reprodução Animal, 31(Xvii), 205-211.

Baruselli, P. S., Catussi, B. L. C., \& Bayeux, B. M. (2019). Estratégias para aumentar a produção de embriões em bovinos. Rev. Bras. Reprod. Anim, 43(2), $315-326$.

Brackett, R. G., \& Zuelke, K. A. (1993). Analysis of factors involved in the in vitro production of bovine embryos. Theriogenology, 39, 43-64.

Bueno, A. P., \& Beltran, M. P. (2008). Produção in vitro de Embriões. Revista Científica Eletrônica de Medicina Veterinária, 11, 1-7.

Ferreira, R. M., Ayres, H., Chiaratti, M. R., Ferraz, M. L., Araújo, A. B., Rodrigues, C. A., Watanabe, Y. F., Vireque, A. A., Joaquim, D. C., Smith, L. C., Meirelles, F. V., \& Baruselli, P. S. (2011). The low fertility of repeat-breeder cows during summer heat stress is related to a low oocyte competence to develop into blastocysts. Journal of Dairy Science, 94(5), 2383-2392. https://doi.org/10.3168/jds.2010-3904

Gaviraghi, A., Deriu, F., Soggiu, A., Galli, A., Bonacina, C., Bonizzi, L., \& Roncada, P. (2010). Proteomics to investigate fertility in bulls. Veterinary Research Communications, 34(SUPPL.1), 34-37. https://doi.org/10.1007/s11259-010-9387-0

Gillan, L., Kroetsch, T., Chis Maxwell, W. M., \& Evans, G. (2008). Assessment of in vitro sperm characteristics in relation to fertility in dairy bulls. Animal Reproduction Science, 103(3-4), 201-214. https://doi.org/10.1016/j.anireprosci.2006.12.010

Gimenes, L. U., Ferraz, M. L., Fantinato-Neto, P., Chiaratti, M. R., Mesquita, L. G., Sá Filho, M. F., Meirelles, F. V., Trinca, L. A., Rennó, F. P., Watanabe, Y. F., \& Baruselli, P. S. (2015). The interval between the emergence of pharmacologically synchronized ovarian follicular waves and ovum pickup does not significantly affect invitro embryo production in Bos indicus, Bos taurus, and Bubalus bubalis. Theriogenology, 83(3), 385-393. https://doi.org/10.1016/j.theriogenology.2014.09.030

Govindaraju, A., Uzun, A., Robertson, L. S., Atli, M. O., Kaya, A., Topper, E., Crate, E. A., Padbury, J., Perkins, A., \& Memili, E. (2012). Dynamics of microRNAs in bull spermatozoa. Reproductive Biology and Endocrinology, 10, 1-10. https://doi.org/10.1186/1477-7827-10-82

Guerreiro, B. M., Batista, E. O. S., Vieira, L. M., Sá Filho, M. F., Rodrigues, C. A., Castro Netto, A., Silveira, C. R. A., Bayeux, B. M., Dias, E. A. R., Monteiro, F. M., Accorsi, M., Lopes, R. N. V. R., \& Baruselli, P. S. (2014). Plasma anti-mullerian hormone: An endocrine marker for invitro embryo production from Bos taurus and Bos indicus donors. Domestic Animal Endocrinology, 49(1), 96-104. https://doi.org/10.1016/j.domaniend.2014.07.002

Heikinheimo, O., \& Gibbons, W. E. (1998). The molecular mechanisms of oocyte maturation and early embryonic development are unveiling new insights into reproductive medicine. Molecular Human Reproduction, 4(8), 745-756. https://doi.org/10.1093/molehr/4.8.745

Heinzen, B. C., Pereira, J. F. S., Fernandes, M. B., Bruel, N. L., Silva, J. J., Dijkinga, F. J., \& Sotomaior, C. S. (2014). Produção in vitro de embriões nas raças Red Angus, Senepol e Girolando. Revista Acadêmica Ciências Agrárias e Ambientais, 12(1), 41.

IETS 2018. Internacional embryo transfer society. (2019). Statistics of embryo production and transfer in domestic farm animals. Embryo Technology Newsletter, 36(4).

Ireland, J. J., Ward, F., Jimenez-Krassel, F., Ireland, J. L. H., Smith, G. W., Lonergan, P., \& Evans, A. C. O. (2007). Follicle numbers are highly repeatable within individual animals but are inversely correlated with FSH concentrations and the proportion of good-quality embryos after ovarian stimulation in cattle. 
Human Reproduction, 22(6), 1687-1695. https://doi.org/10.1093/humrep/dem071

Ireland, J. J., Zielak-Steciwko, A. E., Jimenez-Krassel, F., Folger, J., Bettegowda, A., Scheetz, D., Walsh, S., Mossa, F., Knight, P. G., Smith, G. W., Lonergan, P., \& Evans, A. C. O. (2009). Variation in the ovarian reserve is linked to alterations in intrafollicular estradiol production and ovarian biomarkers of follicular differentiation and oocyte quality in cattle. Biology of Reproduction, 80(5), 954-964. https://doi.org/10.1095/biolreprod.108.073791

Ireland, J. L. H., Scheetz, D., Jimenez-Krassel, F., Themmen, A. P. N., Ward, F., Lonergan, P., Smith, G. W., Perez, G. I., Evans, A. C. O., \& Ireland, J. J. (2008). Antral follicle count reliably predicts number of morphologically healthy oocytes and follicles in ovaries of young adult cattle. Biology of Reproduction, 79(6), 1219-1225. https://doi.org/10.1095/biolreprod.108.071670

Khatib, H., Huang, W., Wang, X., Tran, A. H., Bindrim, A. B., Schutzkus, V., Monson, R. L., \& Yandell, B. S. (2009). Single gene and gene interaction effects on fertilization and embryonic survival rates in cattle. Journal of Dairy Science, 92(5), 2238-2247. https://doi.org/10.3168/jds.2008-1767

Lacerda, I. P. de., Dode, M. A. N., Lima, M. M. S., Guerra, B. F., Costa, E. S., Moreira, G. R., \& Carvalho, J. de O. (2020). Cattle breed affects in vitro embryo production in a large-scale commercial program on dairy farms. Livestock Science, 240(June), 104135. https://doi.org/10.1016/j.livsci.2020.104135

Loiola, M. V. G., Chalhoub, M., Rodrigues, A. S., Ferraz, P. A., Bittencourt, R. F., \& Filho, A. de L. R. (2014). Validação de um programa de produção in vitro de embriões bovinos com transporte de oócitos e de embriões por longas distâncias. Ciencia Animal Brasileira, 15(1), 93-101. https://doi.org/10.5216/cab.v15i1.23327

Lopes, A. C., Palhão, M. P., Fernandes, C. A. C., Sudano, M. J., Castilho, A. C. S., \& Caixeta, E. S. (2017). Differential expression of insulin-like growth factor family members in immature cumulus-oocyte complexes from dairy cows with different genotypes. Reproduction in Domestic Animals, 52(6), 10671073. https://doi.org/10.1111/rda.13028

Machado, G. M., Carvalho, J. O., Filho, E. S., Caixeta, E. S., Franco, M. M., Rumpf, R., \& Dode, M. A. N. (2009). Effect of Percoll volume, duration and force of centrifugation, on in vitro production and sex ratio of bovine embryos. Theriogenology, 71(8), 1289-1297. https://doi.org/10.1016/j.theriogenology.2009.01.002

Mello, R. R. C., Ferreira, J. E., Sousa, S. L. G., Mello, M. R. B., \& Palhano, H. B. (2016). Produção in vitro (PIV) de embriões em bovinos. Revista Brasileira de Reprodução Animal, 40(2), 58-64.

Monteiro, F. M., Batista, E. O. S., Vieira, L. M., Bayeux, B. M., Accorsi, M., Campanholi, S. P., Dias, E. A. R., Souza, A. H., \& Baruselli, P. S. (2017). Beef donor cows with high number of retrieved COC produce more in vitro embryos compared with cows with low number of COC after repeated ovum pick-up sessions. Theriogenology, 90, 54-58. https://doi.org/10.1016/j.theriogenology.2016.11.002.

Negreiros, M. P. M., Seugling, G. H. F., Almeida, A. B. M., Hidalgo, M, M, T., Martins, M, I, M., Blaschi, W., \& Barreiros, T.R.R. Influence of the antral follicle count, body condition score and weight gain in the pregnancy rate of Nelore cows subjected to fixed-time artificial insemination. Research, Society and Development, 9, e907998091. http://dx.doi.org/10.33448/rsd-v9i9.8091

Oliveira, C. S., Serapião, R. V., Camargo, A. J. R., Ferreiro, M. B. D., Freitas, C., \& Verneque, R. S. (2013). Produção in vitro de embriões bovinos F1 a partir de doadoras de oócitos da raça Gir Leiteiro e Holandesa. Slimpósio Brasileiro de Melhoramento Animal.

Paula-Lopes, F. F., Chase, C. C., Al-Katanani, Y. M., Krininger, C. E., Rivera, R. M., Tekin, S., Majewski, A. C., Ocon, O. M., Olson, T. A., \& Hansen, P. J. (2003). Genetic divergence in cellular resistance to heat shock in cattle: Differences between breeds developed in temperate versus hot climates in responses of preimplantation embryos, reproductive tract tissues and lymphocytes to increased culture temperatures. Reproduction, 125(2), 285-294. https://doi.org/10.1530/rep.0.1250285

Pontes, J. H. F., Silva, K. C. F., Basso, A. C., Rigo, A. G., Ferreira, C. R., Santos, G. M. G., Sanches, B. V., Porcionato, J. P. F., Vieira, P. H. S., Faifer, F. S., Sterza, F. A. M., Schenk, J. L., \& Seneda, M. M. (2010). Large-scale in vitro embryo production and pregnancy rates from Bos taurus, Bos indicus, and indicus-taurus dairy cows using sexed sperm. Theriogenology, 74(8), 1349-1355. https://doi.org/10.1016/j.theriogenology.2010.06.004

Roncoletta, M., Morani, E. D. S. C., Esper, C. R., Barnabe, V. H., \& Franceschini, P. H. (2006). Fertility-associated proteins in Nelore bull sperm membranes. Animal Reproduction Science, 91(1-2), 77-87. https://doi.org/10.1016/j.anireprosci.2005.03.014

Sales, J. N. S., Iguma, L. T., Batista, R. I. T. P., Quintão, C. C. R., Gama, M. A. S., Freitas, C., Pereira, M. M., Camargo, L. S. A., Viana, J. H. M., Souza, J. C., \& Baruselli, P. S. (2015). Effects of a high-energy diet on oocyte quality and in vitro embryo production in Bos indicus and Bos taurus cows. Journal of Dairy Science, 98(5), 3086-3099. https://doi.org/10.3168/jds.2014-8858

Santl, B., Wenigerkind, H., Schervnthaner, W., Mödl, J., Stojkovic, M., Prelle, K., Holtz, W., Brem, G., \& Wolf, E. (1998). Comparison of ultrasound-guided vs laparoscopic transvaginal ovum pick-up (OPU) in Simmental heifers. Theriogenology, 50, 89-100.

Santos, J. E. P., Cerri, R. L. A., \& Sartori, R. (2008). Nutritional management of the donor cow. Theriogenology, 69(1), 88-97. https://doi.org/10.1016/j.theriogenology.2007.09.010

Seneda, M. M., Esper, C. R., Garcia, J. M., Oliveira, J. A. de., \& Vantini, R. (2001). Relationship between follicle size and ultrasound-guided transvaginal oocyte recovery. Animal Reproduction Science, 67(1-2), 37-43. https://doi.org/10.1016/S0378-4320(01)00113-0

Silva-Santos, K. C., Santos, G. M. G., Siloto, L. S., Hertel, M. F., Andrade, E. R., Rubin, M. I. B., Sturion, L., Melo-Sterza, F. A., \& Seneda, M. M. (2011). Estimate of the population of preantral follicles in the ovaries of Bos taurus indicus and Bos taurus taurus cattle. Theriogenology, 76(6), 1051-1057. https://doi.org/10.1016/j.theriogenology.2011.05.008

Silva, A. P. T. B., Mello, R. R. C., Ferreira, J. E., \& Mello, M. R. B. (2015). Efeito do acasalamento entre a doadora e o touro (Holandês versus Gir) na produção in vitro de embriões bovinos. Boletim de Indústria Animal, 72(1), 51-58. https://doi.org/10.17523/bia.v72n1p51

Tamassia, M., Heyman, Y., Lavergne, Y., Richard, C., Gelin, V., Renard, J. P., \& Chastant-Maillard, S. (2003). Evidence of oocyte donor cow effect over oocyte production and embryo development in vitro. Reproduction, 126(5), 629-637. https://doi.org/10.1530/rep.0.1260629 
Research, Society and Development, v. 10, n. 7, e38810716712, 2021

(CC BY 4.0) | ISSN 2525-3409 | DOI: http://dx.doi.org/10.33448/rsd-v10i7.16712

Van Wagtendonk-De Leeuw, A. M. (2006). Ovum Pick Up and in Vitro Production in the bovine after use in several generations: A 2005 status. Theriogenology, 65(5 SPEC. ISS.), 914-925. https://doi.org/10.1016/j.theriogenology.2005.09.007

Viana, J. H. M., De Almeida Camargo, L. S., De Moraes Ferreira, A., De Sa, W. F., De Carvalho Fernandes, C. A., \& De Pinho Marques, A. (2004). Short intervals between ultrasonographically guided follicle aspiration improve oocyte quality but do not prevent establishment of dominant follicles in the Gir breed (Bos indicus) of cattle. Animal Reproduction Science, 84(1-2), 1-12. https://doi.org/10.1016/j.anireprosci.2003.12.002

Watanabe, Y. F., de Souza, A. H., Mingoti, R. D., Ferreira, R. M., Santana Batista, E. O., Dayan, A., Watanabe, O., Meirelles, F. V., Nogueira, M. F. G., Ferraz, J. B. S., \& Baruselli, P. S. (2017). Number of oocytes retrieved per donor during OPU and its relationship with in vitro embryo production and field fertility following embryo transfer. Animal Reproduction, 14(3), 635-644. https://doi.org/10.21451/1984-3143-AR1008

Wrenzycki, C. (2016). Sistemas de cultivo in vitro: quão longe estamos das condições ideais? Reunião Anual Da Sociedade Brasileira De Tecnologia De Embriões, 1550-1559.

Xu, J., Guo, Z., Su, L., Nedambale, T. L., Zhang, J., Schenk, J., Moreno, J. F., Dinnyés, A., Ji, W., Tian, X. C., Yang, X., \& Du, F. (2006). Developmental potential of vitrified Holstein cattle embryos fertilized in vitro with sex-sorted sperm. Journal of Dairy Science, 89(7), 2510-2518. https://doi.org/10.3168/jds.S0022-0302(06)72326-8 